\title{
Development of a five-gene signature as a novel prognostic marker in ovarian cancer
}

\author{
R. WANG ${ }^{1, *, *}$, X. H. YE $E^{2, *}$, X. L. ZHAO ${ }^{1}$, J. L. LIU' ${ }^{1}$, C. Y. ZHANG ${ }^{1}$ \\ ${ }^{1}$ Department of Gynecology and Obstetrics, Affiliated Heping Hospital of Changzhi Medical College, Changzhi Medical College, Changzhi \\ 046000, China; ${ }^{2}$ Department of Radiotherapy, First Affiliated Hospital of Zhejiang University School of Medicine, Zhejiang University School of \\ Medicine, Hangzhou 310003, China
}

${ }^{*}$ Correspondence: Rwang_cz@aliyun.com

"Contributed equally to this work.

Received July 5, 2018 / Accepted October 29, 2018

\begin{abstract}
The prognosis of ovarian cancer (OC) remains poor. Thus, the present study aims to identify independent prognostic factor in OC patients. OC gene expression studies GSE26712 and TCGA-OV were included in this study. Prognosis-associated differentially expressed genes (DEGs) between normal ovarian tissue and OC were identified. LASSO Cox proportional hazards regression model was conducted and a prognostic signature was constructed based on these DEGs. The predictive ability of the signature was analyzed in the training set and test set. The prognosis performance of the signature was compared with CA-125 and HE4. Gene set enrichment analysis (GSEA) was conducted to identify relevant mechanism. 332 DEGs were identified, out of which 64 DEGs were significantly correlated with the overall survival (OS) of OC patients, and 5 DEGs (IGF2, PEG3, DCN, LYPD1 and RARRES1) were applied to build a 5-gene signature. Patients in the 5 -gene signature low-risk group had significantly better OS compared to those in the 5-gene high-risk group ( $\mathrm{p}=0.0004$ ) in the training set. Similar results were found in the test set, and the signature was also an independent prognostic factor. The prognosis performance of the 5-gene signature was significantly better than that of CA-125 and HE4. GSEA suggested that OC samples in the 5-gene high-risk group were significantly enriched in $\mathrm{WNT} / \beta$-catenin signaling and epithelialmesenchymal transition. We developed and validated a 5-gene signature that might be used as an independent prognostic factor in patients with OS.
\end{abstract}

Key words: ovarian cancer; prognostic signature; overall survival

Ovarian cancer (OC) represents the most lethal type of gynecological malignance and is a clinically heterogeneous disease as demonstrated through associations with family history of cancer, genetic risk and histopathology of this disease $[1,2]$. Epithelial cancer accounts for about $95 \%$ of the OC [2]. Owing to the fact that nearly $70 \%$ of OC patients are diagnosed at stages III and IV according to the International Federation of Gynecology and Obstetrics (FIGO) and that more than $30 \%$ of OC patients will develop acquired chemoresistance and eventually relapse, the 5 -year overall survival remains poor [3, 4]. Thus, developing novel prognostic tools to stratify seemingly identical patients and redirect them to more precise therapies is of great importance. There have been many recent improvements in the sequencing technology. Subsequently, a variety of OC gene expression studies have been published $[5,6]$. Therefore, in this study we developed and validated a five-gene based prognostic signature for patients with OC. It has been reported that these five genes (IGF2 [7], PEG3 [8], DCN [9], LYPD1[10] and RARRES1[11]) were associated with survival and cell growth of multiple human cancers.

\section{Materials and methods}

OC gene expression studies. OC gene expression study GSE26712 [5] and TCGA-OV [12] were included in this study. GSE26712, which included 195 ovary tissue samples (10 normal, 185 malignant) was used as a training set. TCGA-OV, which included 564 patients whose survival time was fully documented, was used as a test set.

Data processing and analysis. Raw data of GSE26712 was downloaded from gene expression omnibus (GEO) 
database and preprocessed and normalized using R "affy" package [13], and then the DEGs between normal ovarian tissue and OC were calculated using R package "limma" [14]. Genes at $\left|\log _{2} \mathrm{FC}\right|>2$ and adjusted $\mathrm{p}<0.05$ were treated as DEGs. Log-rank based survival analyses were conducted to identify DEGs that were significantly correlated with the overall survival (OS) of patients with OC. LASSO Cox regression model was applied to select prognostic DEGs to predict the OS by 10 -fold cross-validation and the risk scores for each patient were calculated using R package "glmnet" [15]. Time-dependent receiver operating characteristic curve (ROC) analysis was conducted to find the optimal cut-off and stratify OC patients into low-risk group and high-risk group in the training set and test set [16]. Thus, we constructed a prognostic signature on the basis of LASSO Cox regression model. Logistic regression model and Cox proportional hazards regression model were performed to analyze the relation between the clinical features of OC patients and the 5-gene signature and to identify prognostic factors in OC. Odds ratios (ORs) or hazards ratios (HRs) and associated confidence intervals (CIs) were calculated using maximum likelihood estimates, along with Wald test

Table 1. Characteristics of $\mathrm{OC}$ patients in the test set.

\begin{tabular}{|c|c|c|c|c|c|c|c|}
\hline \multirow{2}{*}{ Variable } & \multirow{2}{*}{ total number } & \multicolumn{2}{|c|}{ Group } & \multicolumn{4}{|c|}{ Logistic regression analysis } \\
\hline & & Low-risk & High-risk & OR & LCI & UCI & p-value \\
\hline \multicolumn{8}{|l|}{ Age (year) } \\
\hline$<60$ & 295 & 112 & 183 & \multirow{2}{*}{1.002} & \multirow{2}{*}{0.987} & \multirow{2}{*}{1.017} & \multirow{2}{*}{0.783} \\
\hline$\geq 60$ & 269 & 107 & 162 & & & & \\
\hline \multicolumn{8}{|l|}{ Stage } \\
\hline Early stage & 46 & 26 & 20 & \multirow{2}{*}{0.872} & \multirow{2}{*}{0.778} & \multirow{2}{*}{0.974} & \multirow{2}{*}{0.016} \\
\hline Late stage & 518 & 193 & 325 & & & & \\
\hline \multicolumn{8}{|l|}{ Grade } \\
\hline Grade 1 & 9 & 7 & 2 & \multirow{4}{*}{0.719} & \multirow{4}{*}{0.481} & \multirow{4}{*}{1.068} & \multirow{4}{*}{0.103} \\
\hline Grade 2 & 69 & 28 & 41 & & & & \\
\hline Grade 3 & 476 & 178 & 298 & & & & \\
\hline NA & 10 & 6 & 4 & & & & \\
\hline
\end{tabular}

Abbreviations: OR, odds ratio; LCI, lower limit of confidence interval; UCI, upper limit of confidence.

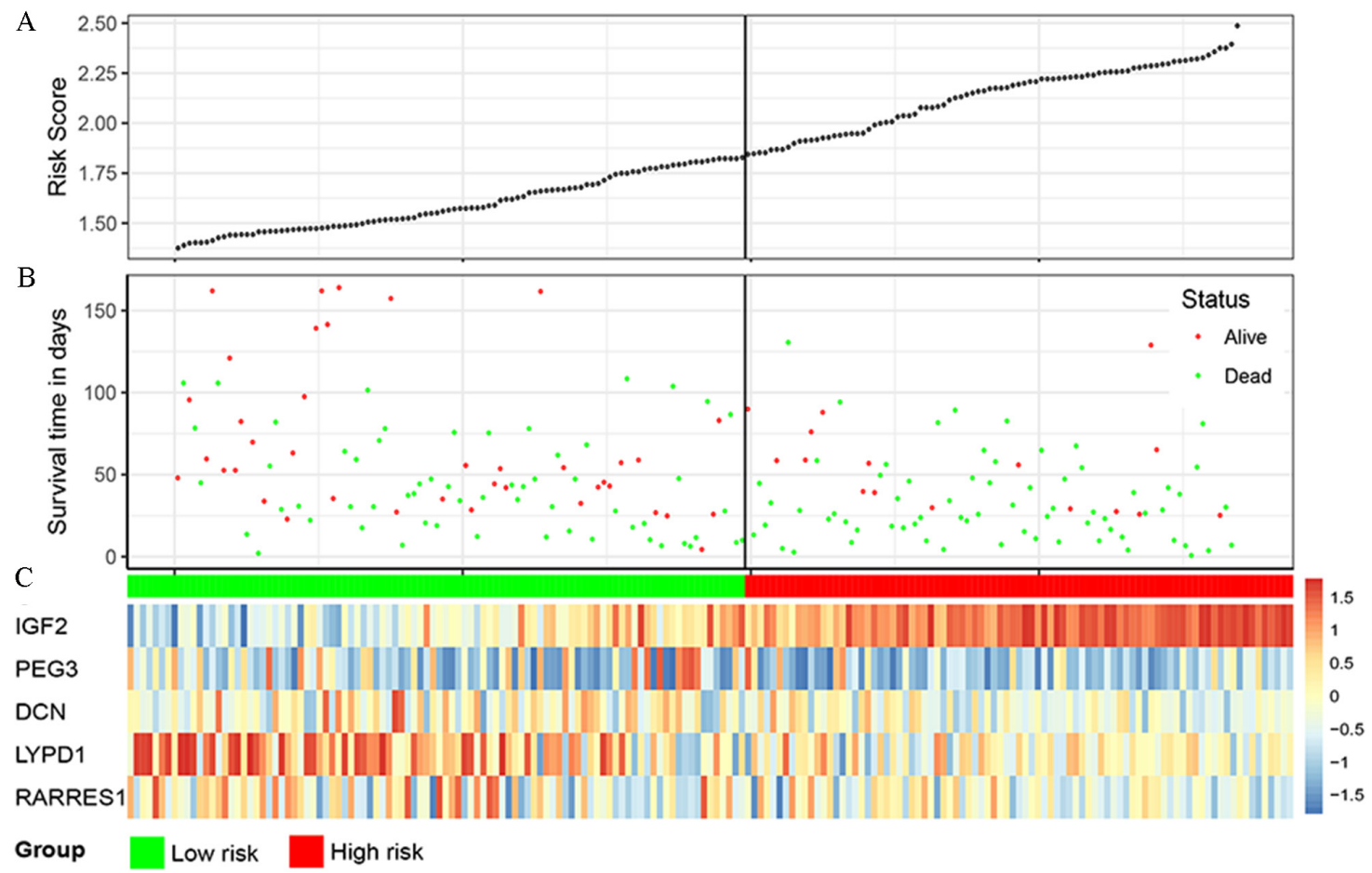

Figure 1. Characteristics of the 5-gene prognostic signature. A) the risk of each OC patients. B) the overall survival and survival status of each OC patients. C) heat-map of the 5 genes in the signature. 
p-values. Thus, the prognostic role of the signature was investigated in the training set and test set. C-index, also known as concordance index, provides a global assessment of a fitted survival model. To evaluate the performance of the 5-gene signature, we compared the $\mathrm{C}$-index of the 5-gene signature with other prognostic biomarkers (CA-125 and HE4) [17] using R package "survcomp [18]". Finally, to identify potentially relevant mechanisms that were associated with the OC patient survival, gene set enrichments analysis (GSEA) was conducted, and gene set at nominal $\mathrm{p}<0.05$ and false discovery rate (FDR) $<25 \%$ were treated as significantly enriched $[19,20]$.

\section{Results}

Characteristics of OC patients. A total of 185 high grade, advanced stage $\mathrm{OC}$ patients were included in the training set and the age of OC patients was not available. Meanwhile, a total of 564 OC patients were included in the TCGA-OV data set (the test set), of which 295 (52.3\%) OC patients were younger than 60 years old and the remaining 269 OC patients were not younger than 60 years. Regarding the stage, $46(8.2 \%)$ patients were early stage OC and 518 (91.8\%) OC patients were advanced stage OC in the test set. As for the grade, $9(1.6 \%)$ patients were grade 1 OC, $69(12.2 \%)$ patients were grade $2 \mathrm{OC}$ and $474(84.4 \%)$ patients were grade $3 \mathrm{OC}$ in the test set (Table 1).

Prognostic signature construction. As shown in Table S1, a total of 332 DEGs were identified between normal ovarian tissue and $\mathrm{OC}$ in the training set (Table S1). Then, 64 genes were significantly correlated with the OS of the OC patients using univariate Cox proportional hazards regression analysis (Table S2). We then constructed a 5-gene based prognostic signature using L1-penalized Cox proportional hazards regression on the training set (Figure 1, Table S3).

The prognostic role of the 5-gene signature in $\mathrm{OC}$. We divided the OC patients into the 5-gene signature low-risk group and high-risk group on the basis of the cutoff (1.575) calculated using the time-dependent ROC analysis (Figure 2A). As shown in Figure 2B, patients in the 5-gene signature low-risk group had significantly better OS compared to those in the 5-gene high-risk group ( $\mathrm{HR}=$ 0.5391, 95\% CI: 0.3801-0.7646, $\mathrm{p}=0.0004$ ).

Validation of the prognostic role of the 5-gene signature in the test set. To validate the predictive role of the 5-gene signature, we first performed logistic regression analysis. As shown in Table 1, the 5-gene signature was significantly correlated with the stage of OC patients $(\mathrm{OR}=0.872,95 \% \mathrm{CI}$ : $0.778-0.974, \mathrm{p}=0.016$, Table 1$)$. The results of $\mathrm{KM}$ survival analysis suggest that the OS favors patients in 5-gene signature low-risk group over those in high-risk group $(\mathrm{HR}=$ 0.6186, 95\% CI: 0.4849-0.7891, p=0.0001, Figure 3A) in the test set. Furthermore, although the 5-gene signature did not play a prognostic role in patients with early stage $\mathrm{OC}(\mathrm{HR}=$
0.4689, 95\% CI: 0.1196-1.839, $\mathrm{p}=0.3$, Figure 3B), a lower risk of signature was related with significantly better prognosis of patients with advanced stage $\mathrm{OC}(\mathrm{HR}=0.6274,95 \% \mathrm{CI}$ : $0.4892-0.8047, p=0.0002$, Figure $3 C$ ) in the set. Univariate and multivariable hazards regression analysis suggest that the 5 -gene signature is an independent prognostic factor for OC (Table 2). Meanwhile, the results of Kaplan-Meier survival analysis suggest that lower expression of IGF2, DCN, LYPD1 and RARRES1 is associated with better OS in the training set and test set (Figure S1 and Figure S2).

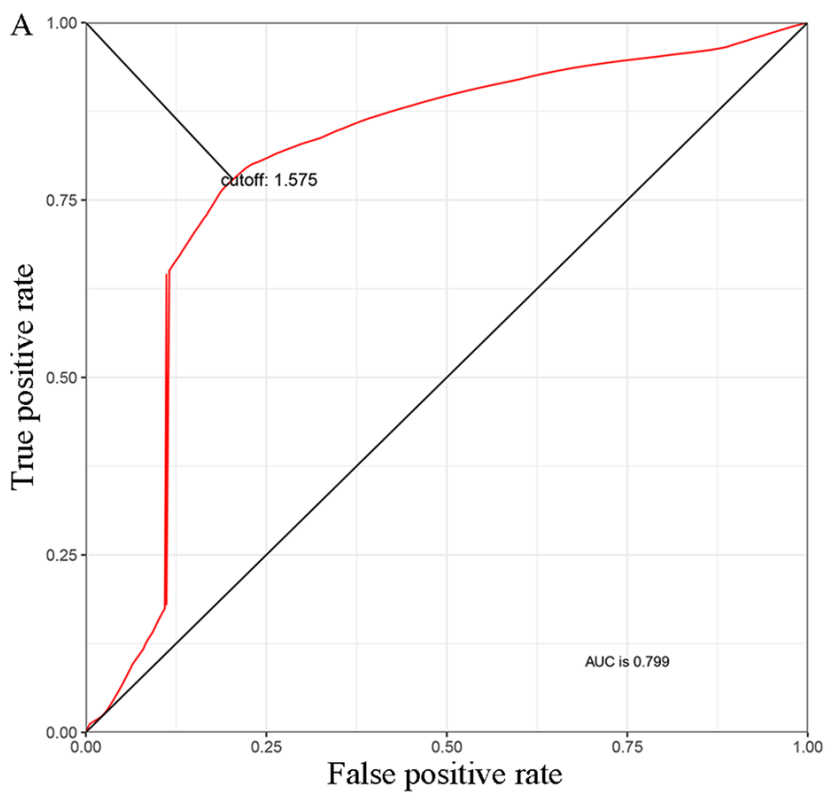

B
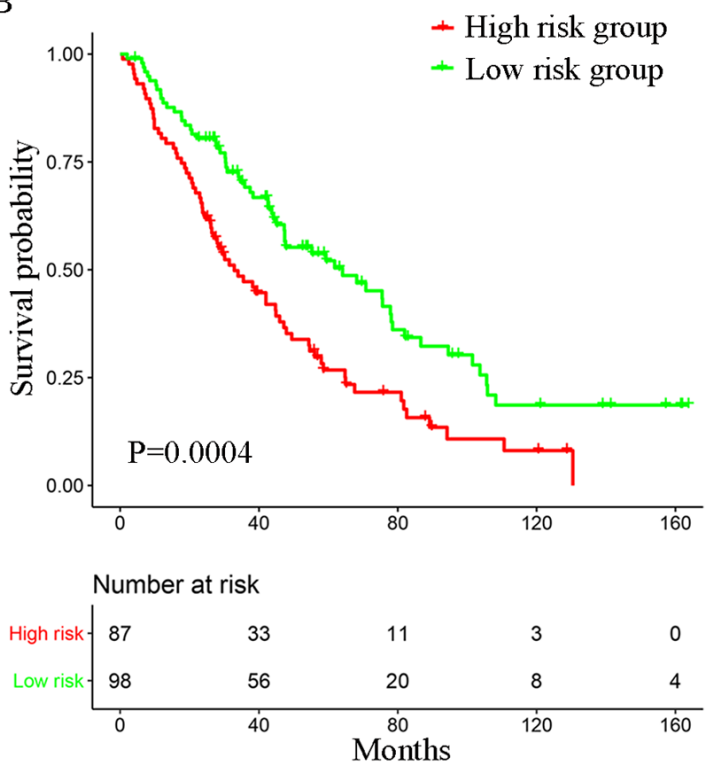

Figure 2. The prognostic role of the 5-gene signature in the training set. A) time-dependent survival ROC analysis. B) the overall survival of patients in low-risk group and high-risk group. 


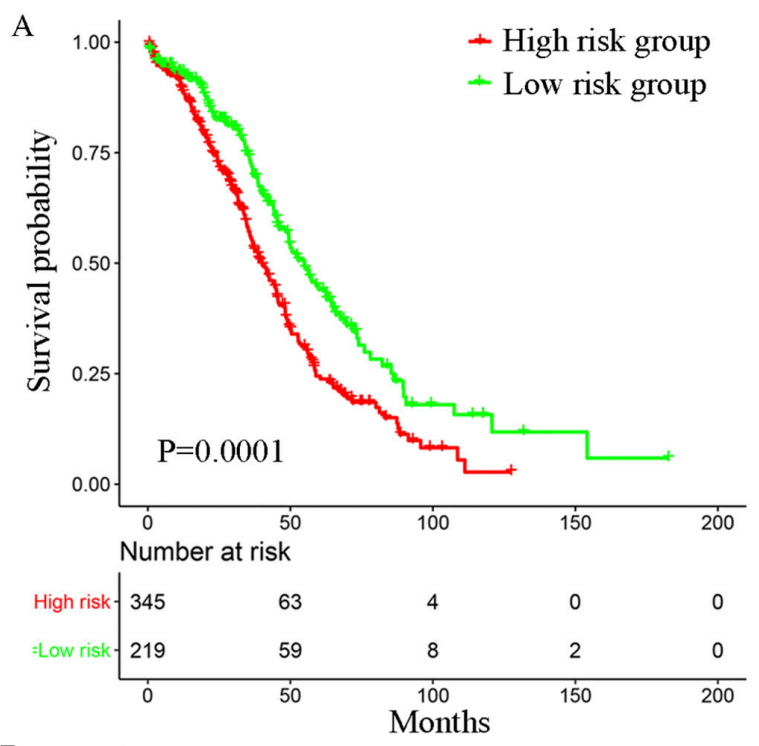

B

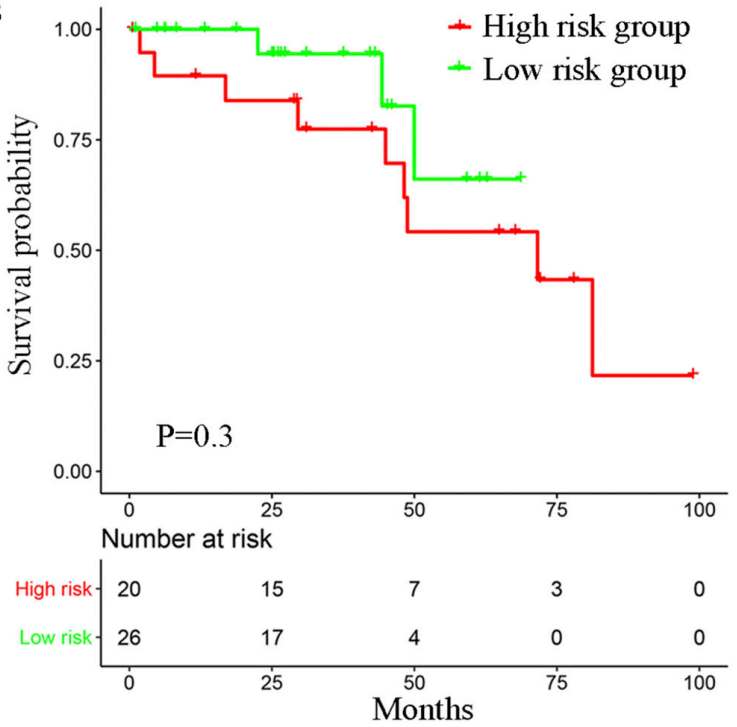

C

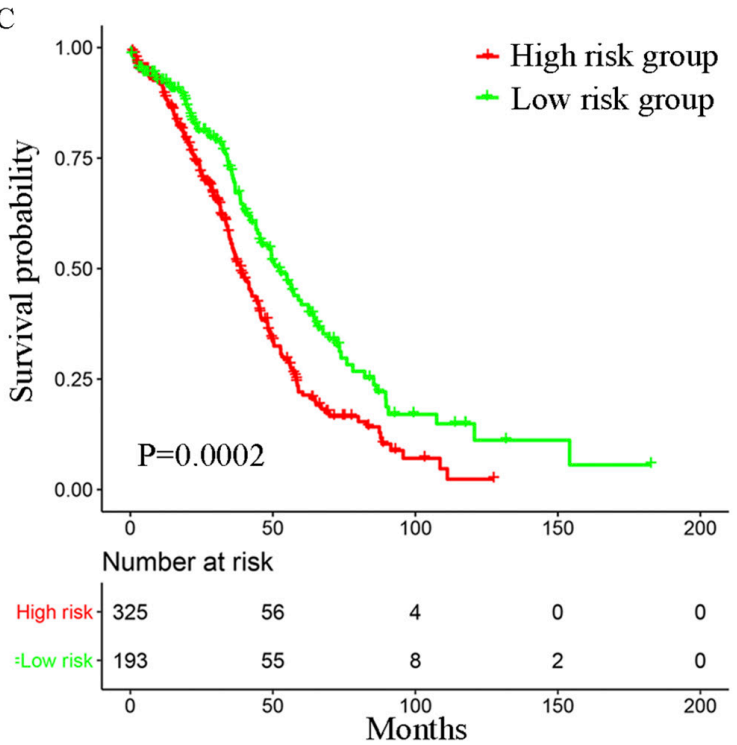

Comparison of the prognostic performance between the 5-gene signature and CA-125 and HE4. CA 125, also known as mucin 16 (MUC16), is a large membrane glycoprotein belonging to the wide mucin family and widely used as a tumor marker of OC [21]. Human epididymis protein 4 (HE4) is the FDC2 (HE4) gene product that has been treated as a new biomarker in OC[22]. Thus, we compared the prognosis performance of the 5-gene signature with CA-125 and HE4 in the TCGA ovarian cancer cohort $(n=564)$. As shown in Figure 4, the C-index for the 5-gene signature is significantly higher compared to that for CA- 125 (0.686 vs $0.539, \mathrm{p}<0.001)$ and HE4 (0.686 vs $0.576, \mathrm{p}<0.001)$ (Figure 4). GSEA of OC samples. Finally, we conducted GSEA to find associated mechanisms confirming that the 5-gene signature affected the prognosis of patients with OC. As shown in Figure 5, OC samples in the 5-gene high-risk group were significantly enriched in WNT/ $\beta$-catenin signaling (enrichment score: 0.514782, P: 0.024, FDR: 18.83\%) and epithelialmesenchymal transition (EMT) (enrichment score: 0.706814 , $\mathrm{p}=0.0397$, FDR: $5.07 \%)$.

\section{Discussion}

In this study, we identified DEGs between normal ovarian tissue and OC cells, identified prognostic DEGs correlated with the OS of OC patients, and a 5-gene signature was constructed after these prognostic DEGs were included into a Cox proportional hazards regression model combined with the least absolute shrinkage and selection operator. The prognostic role of the 5-gene signature was analyzed and validated in the training set and test set. Finally, GSEA was conducted to investigate potentially relevant mechanism.

Five genes in the prognostic signature were IGF2, PEG3, DCN, LYPD1 and RARRES1. In fact, there were several studies that have reported the 5 genes in the cancer pathogenesis and progression. Xu et al. suggested that the expression levels of IGF2 and CD133 were positively correlated with each other in primary ESCC [23] and that concurrent upregulation of IGF2 and CD133 expression was significantly related with poor patient prognosis. They were also found to be involved in colorectal cancer, liver cancer, adrenocortical carcinomas, etc. [7, 24, 25]. Meanwhile, Jiang et al. demonstrated that down-regulation of PEG3 stimulated beta-catenin pathway and promoted glioma cell growth, which was similar to the results of our GSEA showing that OC patients in the 5-gene high-risk group were significantly enriched in WNT/betacatenin signaling pathway [26]. Li et al. demonstrated that DCN, accompanied by HSPD1, could be considered as a biomarker for colon cancer [27]. Xu Y et al. demonstrated that decreased expression of DCN promoted proliferation

Figure 3. Validation of the prognostic role in the test set. A) the overall survival of patients in the whole population. B) the overall survival of patients with early stage OC. C) the overall survival of patients with advanced stage $\mathrm{OC}$. 
Table 2. Univariate and multivariable Cox proportional hazards regression analysis on the overall survival of OC patients.

\begin{tabular}{|c|c|c|c|c|c|c|c|c|}
\hline \multirow{2}{*}{ Variable } & \multicolumn{4}{|c|}{ Univariate Cox proportional hazards regression analysis } & \multicolumn{4}{|c|}{ Multivariable Cox proportional hazards regression analysis } \\
\hline & HR & LCI & UCI & p-value & HR & LCI & UCI & p-value \\
\hline Age & 1.021 & 1.01 & 1.032 & $<0.001$ & 1.021 & 1.011 & 1.032 & $<0.001$ \\
\hline Stage & 1.173 & 1.054 & 1.305 & 0.003 & 1.155 & 1.037 & 1.288 & 0.009 \\
\hline Grade & 1.337 & 0.999 & 1.787 & 0.05 & 1.275 & 0.951 & 1.711 & 0.104 \\
\hline 5-gene signature & 3.484 & 1.187 & 10.23 & 0.023 & 3.842 & 1.289 & 11.459 & 0.016 \\
\hline
\end{tabular}

Abbreviations: HR, hazards ratio; LCI, lower limit of confidence interval; UCI, upper limit of confidence interval.

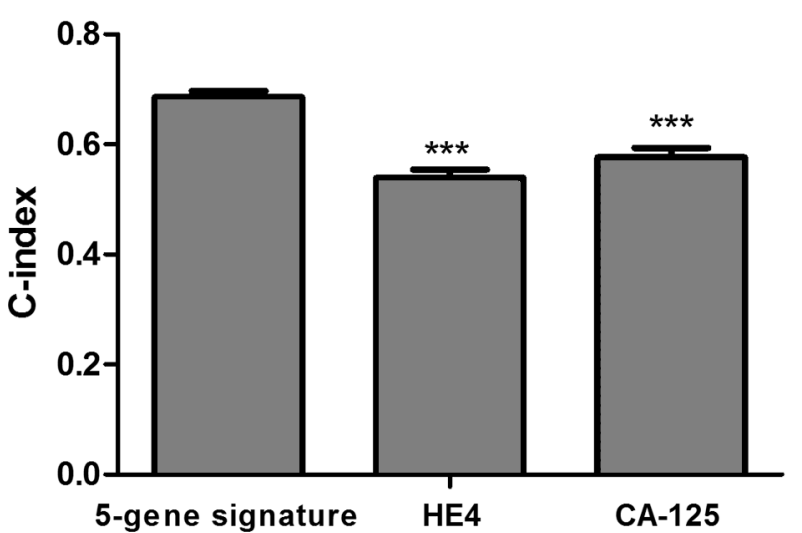

Figure 4. The C-index for the 5-gene signature, CA-125, and HE4. ${ }^{* * *} \mathbf{p}<\mathbf{0 . 0 0 1}$

and metastasis of renal cell carcinoma cells [9]. Burnett et al. demonstrated that LYPD1 was up-regulated in breast cancer cells and was associated with the metastasis of the disease [28]. Oldridge et al. demonstrated that retinoic acid inhibited proliferation and invasion through inducting RARRES1 and LXN [29]. Wu et al. demonstrated that the expression of RARRES1 was significantly associated with tumor differentiation and staging in colorectal adenocarcinoma [11]. The above studies show that our signature might play an important role in the pathogenesis and progression of OC.

The result of GSEA suggest that the 5-gene signature might affect progression of the OC through $W N T / \beta$ catenin signaling and epithelial-mesenchymal transition. Wnt signaling was activated in epithelial OC and niclosamide inhibited the OC growth through suppressing WNT signaling. The Wnt signaling pathway plays a critical role in embryogenesis and oncogenesis. In the canonical Wnt signaling pathway, dysregulation of the Wnt/ $\beta$-catenin signaling pathway has been identified in OC [30]. Mutations in the $\beta$-catenin (CTNNB1) gene leading to alteration of the Wnt/ $\beta$-catenin signaling pathway have been found in the endometrioid subtype of OC $[31,32]$. Aberrant accumulation of $\beta$-catenin is associated with increasing OC grade and poor survival $[33,34]$. In contrast to canonical Wnt signaling, non-canonical Wnt signaling pathways may have transcriptional and non-transcriptional effects [34]. In the non-canonical Wnt/Ca2+ signaling pathway, Wnt ligands

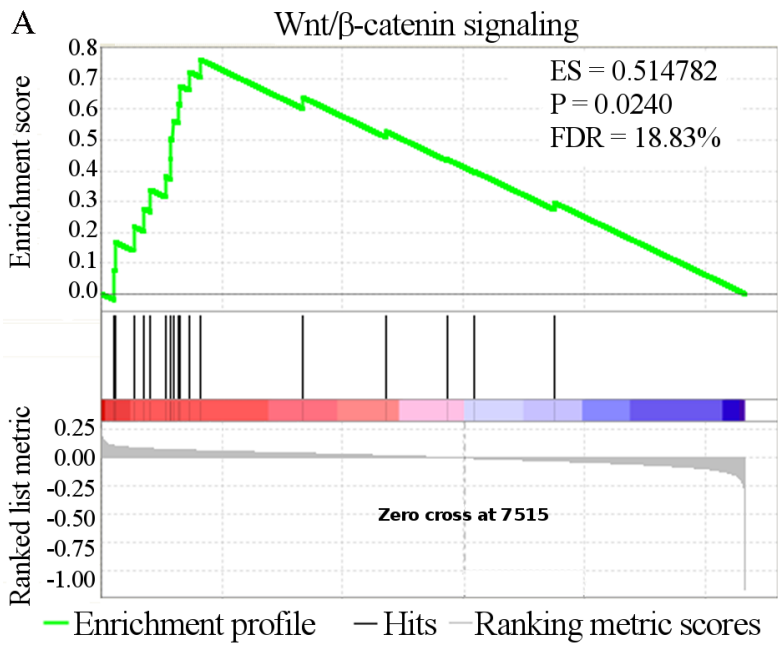

B

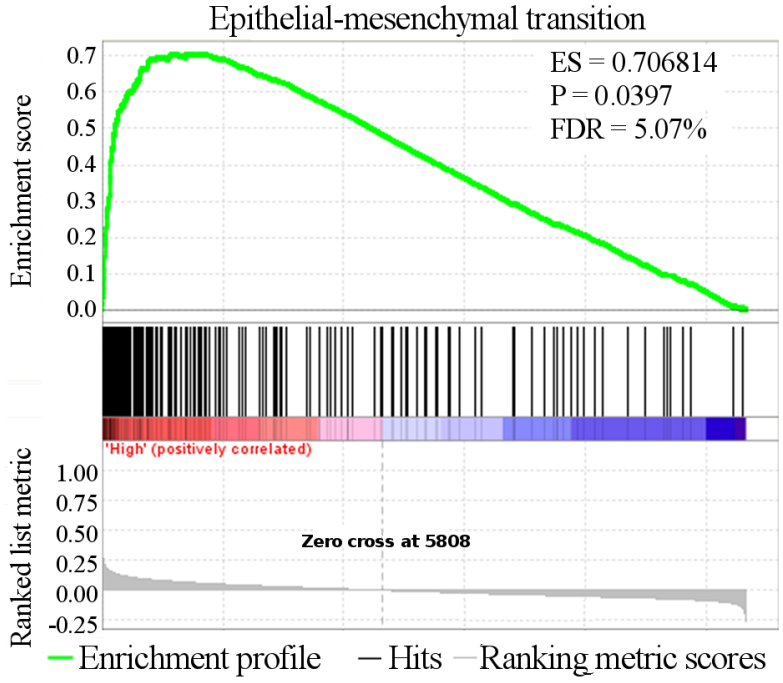

Figure 5. Gene set enrichment analysis of OC samples in the 5-gene signature low-risk group and high-risk group.

binding to Fzd receptors initiate activation of the phospholipase $C$ via $G$ protein-couple receptor signaling, causing an increase in intracellular $\mathrm{Ca} 2+$ and resulting in activation of $\mathrm{Ca} 2+/$ calmodulin-dependent kinase II (CaMKII) and protein kinase C [35]. Meanwhile, previous studies have identified that deregulation of the Wnt/Ca2+ signaling pathway mediates cytoskeleton rearrangements, cellular 
proliferation, cellular motility and epithelial-mesenchymal transition in cancer development and progression [36, 37].

Meanwhile, EMT has been found in multiple human cancers, especially in the metastasis process, where epithelial cells acquire increased motility and invasive properties to become mesenchymal like cells [38]. In OC, EMT promoted migration and invasion ability of the OC cells, contributed to chemoresistance and thus participated in the progression of the disease [39]. This could also explain the clinical role of the 5-gene signature in patients with OC to some extent.

Survival analysis on the 5-gene suggest that it could classify OC patients into high-risk group and low-risk group. Patients in low-risk group were associated with better clinical outcome compared with those in high-risk group. Although the conclusion was validated in an independent cohort, for the sake of caution we propose to conduct multicenter, largescale clinical studies to validate our conclusions in the future.

In conclusion, we developed a 5-gene signature that might be used as an independent prognostic factor in patients with OC.

Supplementary information is available in the online version of the paper.

Acknowledgments: This work was supported by Zhejiang Province Science Technology Foundation (No. 2015C33199).

\section{References}

[1] HALKIA E, CHRELIAS G, CHRELIAS C, ESQUIVEL J. 2017 Update on Ovarian Cancer Peritoneal Carcinomatosis Multimodal-Treatment Considerations. Gastroenterol Res Pract 2018; 2018: 5284814. https://doi.org/10.1155/2018/5284814

[2] ABDULFATAH E, AHMED Q, ALOSH B, BANDYOPADHYAY S, BLUTH MH et al. Gynecologic Cancers: Molecular Updates 2018. Clin Lab Med 2018; 38: 421-438. https://doi. org/10.1016/j.cll.2018.02.007

[3] TYAGI NK, DHESY-THIND S. Clinical practice guidelines in breast cancer. Curr Oncol 2018; 25: S151-S160. https:// doi.org/10.3747/co.25.3729

[4] HENDERSON JT, WEBBER EM, SAWAYA GF. Screening for Ovarian Cancer: Updated Evidence Report and Systematic Review for the US Preventive Services Task Force. JAMA 2018; 319: 595-606. https://doi.org/10.1001/ jama.2017.21421

[5] BONOME T, LEVINE DA, SHIH J, RANDONOVICH $\mathrm{M}$, PISE-MASISON CA et al: A gene signature predicting for survival in suboptimally debulked patients with ovarian cancer. Cancer Res 2008; 68: 5478-5486. https://doi. org/10.1158/0008-5472.CAN-07-6595

[6] MOK SC, BONOME T, VATHIPADIEKAL V, BELL A, JOHNSON ME et al: A gene signature predictive for outcome in advanced ovarian cancer identifies a survival factor: microfibril-associated glycoprotein 2. Cancer Cell 2009; 16: 521-532. https://doi.org/10.1016/j.ccr.2009.10.018
[7] THOMAS H. Liver cancer: IGF2 - an epigenetic oncodriver in HCC. Nat Rev Gastroenterol Hepatol 2016; 13: 625. https://doi.org/10.1038/nrgastro.2016.162

[8] NYE MD, HOYO C, HUANG Z, VIDAL AC, WANG F et al: Associations between methylation of paternally expressed gene 3 (PEG3), cervical intraepithelial neoplasia and invasive cervical cancer. PLoS One 2013; 8: e56325. https://doi. org/10.1371/journal.pone.0056325

[9] XU Y, XIA Q, RAO Q, SHI S, SHI Q et al. DCN deficiency promotes renal cell carcinoma growth and metastasis through downregulation of P21 and E-cadherin. Tumour Biol 2016; 37: 5171-5183. https://doi.org/10.1007/s13277-015-4160-1

[10] YU DH, FAN W, LIU G, NGUY V, CHATTERTON JE et al: PHTS, a novel putative tumor suppressor, is involved in the transformation reversion of HeLaHF cells independently of the p53 pathway. Exp Cell Res 2006; 312: 865-876. https:// doi.org/10.1016/j.yexcr.2005.12.006

[11] WU CC, SHYU RY, CHOU JM, JAO SW, CHAO PC et al. RARRES1 expression is significantly related to tumour differentiation and staging in colorectal adenocarcinoma. Eur J Cancer 2006; 42: 557-565. https://doi.org/10.1016/j. ejca.2005.11.015

[12] CANCER GENOME ATLAS RESEARCH NETWORK. Integrated genomic analyses of ovarian carcinoma. Nature 2011; 474: 609-615. https://doi.org/10.1038/nature10166

[13] GAUTIER L, COPE L, BOLSTAD BM, IRIZARRY RA. affy-analysis of Affymetrix GeneChip data at the probe level. Bioinformatics 2004; 20: 307-315. https://doi.org/10.1093/ bioinformatics/btg 405

[14] RITCHIE ME, PHIPSON B, WU D, HU Y, LAW CW et al. limma powers differential expression analyses for RNAsequencing and microarray studies. Nucleic Acids Res 2015; 43: e47. https://doi.org/10.1093/nar/gkv007

[15] FRIEDMAN J, HASTIE T, TIBSHIRANI R. Regularization Paths for Generalized Linear Models via Coordinate Descent. J Stat Softw 2010; 33: 1-22.

[16] HEAGERTY PJ, LUMLEY T, PEPE MS. Time-dependent ROC curves for censored survival data and a diagnostic marker. Biometrics 2000; 56: 337-344.

[17] STEFFENSEN KD, WALDSTROM M, BRANDSLUND I, PETZOLD M, JAKOBSEN A. The prognostic and predictive value of combined HE4 and CA-125 in ovarian cancer patients. Int J Gynecol Cancer 2012; 22: 1474-1482. https:// doi.org/10.1097/IGC.0b013e3182681cfd

[18] SCHRODER MS, CULHANE AC, QUACKENBUSH J, HAIBE-KAINS B. survcomp: an R/Bioconductor package for performance assessment and comparison of survival models. Bioinformatics 2011; 27: 3206-3208. https://doi. org/10.1093/bioinformatics/btr511

[19] SUBRAMANIAN A, TAMAYO P, MOOTHA VK, MUKHERJEE S, EBERT BL et al: Gene set enrichment analysis: a knowledge-based approach for interpreting genomewide expression profiles. Proc Natl Acad Sci U S A 2005; 102: 15545-15550. https://doi.org/10.1073/pnas.0506580102

[20] MOOTHA VK, LINDGREN CM, ERIKSSON KF, SUBRAMANIAN A, SIHAG S et al: PGC-1alpha-responsive genes involved in oxidative phosphorylation are coordinately downregulated in human diabetes. Nat Genet 2003; 34: $267-$ 273. https://doi.org/10.1038/ng1180 
[21] BOTTONI P, SCATENA R. The Role of CA 125 as Tumor Marker: Biochemical and Clinical Aspects. Adv Exp Med Biol 2015; 867: 229-244. https://doi.org/10.1007/978-94017-7215-0_14

[22] SIMMONS AR, BAGGERLY K, BAST RC JR. The emerging role of HE4 in the evaluation of epithelial ovarian and endometrial carcinomas. Oncology (Williston Park) 2013; 27: 548-556.

[23] XU WW, LI B, ZHAO JF, YANG JG, LI JQ et al. IGF2 induces CD133 expression in esophageal cancer cells to promote cancer stemness. Cancer Lett 2018; 425: 88-100. https://doi. org/10.1016/j.canlet.2018.03.039

[24] CUI H, LIU Y, JIANG J, LIU Y, YANG Z et al. IGF2-derived miR-483 mediated oncofunction by suppressing DLC-1 and associated with colorectal cancer. Oncotarget 2016; 7: 48456-48466. https://doi.org/10.18632/oncotarget.10309

[25] CREEMERS SG, VAN KOETSVELD PM, VAN KEMENADE FJ, PAPATHOMAS TG, FRANSSEN GJ et al: Methylation of IGF2 regulatory regions to diagnose adrenocortical carcinomas. Endocr Relat Cancer 2016; 23: 727-737. https://doi.org/10.1530/ERC-16-0266

[26] JIANG X, YU Y, YANG HW, AGAR NY, FRADO L et al. The imprinted gene PEG3 inhibits Wnt signaling and regulates glioma growth. J Biol Chem 2010; 285: 8472-8480. https:// doi.org/10.1074/jbc.M109.069450

[27] LI G, LI M, LIANG X, XIAO Z, ZHANG P et al. Identifying DCN and HSPD1 as Potential Biomarkers in Colon Cancer Using 2D-LC-MS/MS Combined with iTRAQ Technology. J Cancer 2017; 8: 479-489. https://doi.org/10.7150/jca.17192

[28] BURNETT RM, CRAVEN KE, KRISHNAMURTHY P, GOSWAMI CP, BADVE S et al. Organ-specific adaptive signaling pathway activation in metastatic breast cancer cells. Oncotarget 2015; 6: 12682-12696. https://doi.org/10.18632/ oncotarget. 3707

[29] OLDRIDGE EE, WALKER HF, STOWER MJ, SIMMS MS, MANN VM et al. Retinoic acid represses invasion and stem cell phenotype by induction of the metastasis suppressors RARRES1 and LXN. Oncogenesis 2013; 2: e45. https://doi. org/10.1038/oncsis.2013.6

[30] ZHAO H, WEI W, SUN Y, GAO J, WANG Q et al. Interference with the expression of beta-catenin reverses cisplatin resistance in A2780/DDP cells and inhibits the progression of ovarian cancer in mouse model. DNA Cell Biol 2015; 34: 55-62. https://doi.org/10.1089/dna.2014.2626
[31] BARGHOUT SH, ZEPEDA N, XU Z, STEED H, LEE CH et al. Elevated beta-catenin activity contributes to carboplatin resistance in A2780cp ovarian cancer cells. Biochem Biophys Res Commun 2015; 468: 173-178. https://doi.org/10.1016/j. bbrc.2015.10.138

[32] AREND RC, LONDONO-JOSHI AI, STRAUGHN JM, JR., BUCHSBAUM DJ. The Wnt/beta-catenin pathway in ovarian cancer: a review. Gynecol Oncol 2013; 131: 772-779. https://doi.org/10.1016/j.ygyno.2013.09.034

[33] MCCONECHY MK, DING J, SENZ J, YANG W, MELNYK $\mathrm{N}$ et al: Ovarian and endometrial endometrioid carcinomas have distinct CTNNB1 and PTEN mutation profiles. Mod Pathol 2014; 27: 128-134. https://doi.org/10.1038/modpathol.2013.107

[34] FORD CE, PUNNIA-MOORTHY G, HENRY CE, LLAMOSAS E, NIXDORF S et al. The non-canonical Wnt ligand, Wnt5a, is upregulated and associated with epithelial to mesenchymal transition in epithelial ovarian cancer. Gynecol Oncol 2014; 134: 338-345. https://doi.org/10.1016/j. ygyno.2014.06.004

[35] LIU LJ, XIE SX, CHEN YT, XUE JL, ZHANG CJ et al. Aberrant regulation of Wnt signaling in hepatocellular carcinoma. World J Gastroenterol 2016; 22: 7486-7499. https://doi. org/10.3748/wjg.v22.i33.7486

[36] HUANG L, JIN Y, FENG S, ZOU Y, XU S et al. Role of Wnt/ beta-catenin, Wnt/c-Jun N-terminal kinase and Wnt/Ca(2+) pathways in cisplatin-induced chemoresistance in ovarian cancer. Exp Ther Med 2016; 12: 3851-3858. https://doi. org/10.3892/etm.2016.3885

[37] GREGORY MA, PHANG TL, NEVIANI P, ALVAREZCALDERON F, EIDE CA et al. Wnt/Ca2+/NFAT signaling maintains survival of $\mathrm{Ph}+$ leukemia cells upon inhibition of Bcr-Abl. Cancer Cell 2010; 18: 74-87. https://doi. org/10.1016/j.ccr.2010.04.025

[38] YO YT, LIN YW, WANG YC, BALCH C, HUANG RL et al. Growth inhibition of ovarian tumor-initiating cells by niclosamide. Mol Cancer Ther 2012; 11: 1703-1712. https:// doi.org/10.1158/1535-7163.MCT-12-0002

[39] JEON SY, HWANG KA, CHOI KC. Effect of steroid hormones, estrogen and progesterone, on epithelial mesenchymal transition in ovarian cancer development. J Steroid Biochem Mol Biol 2016; 158: 1-8. https://doi.org/10.1016/j. jsbmb.2016.02.005 


\section{Development of a five-gene signature as a novel prognostic marker in ovarian cancer}

R. WANG ${ }^{1, *, *}$, X. H. YE ${ }^{2, *}$, X. L. ZHAO ${ }^{1}$, J. L. LIU ${ }^{1}$, C. Y. ZHANG ${ }^{1}$

\section{Supplemental material}
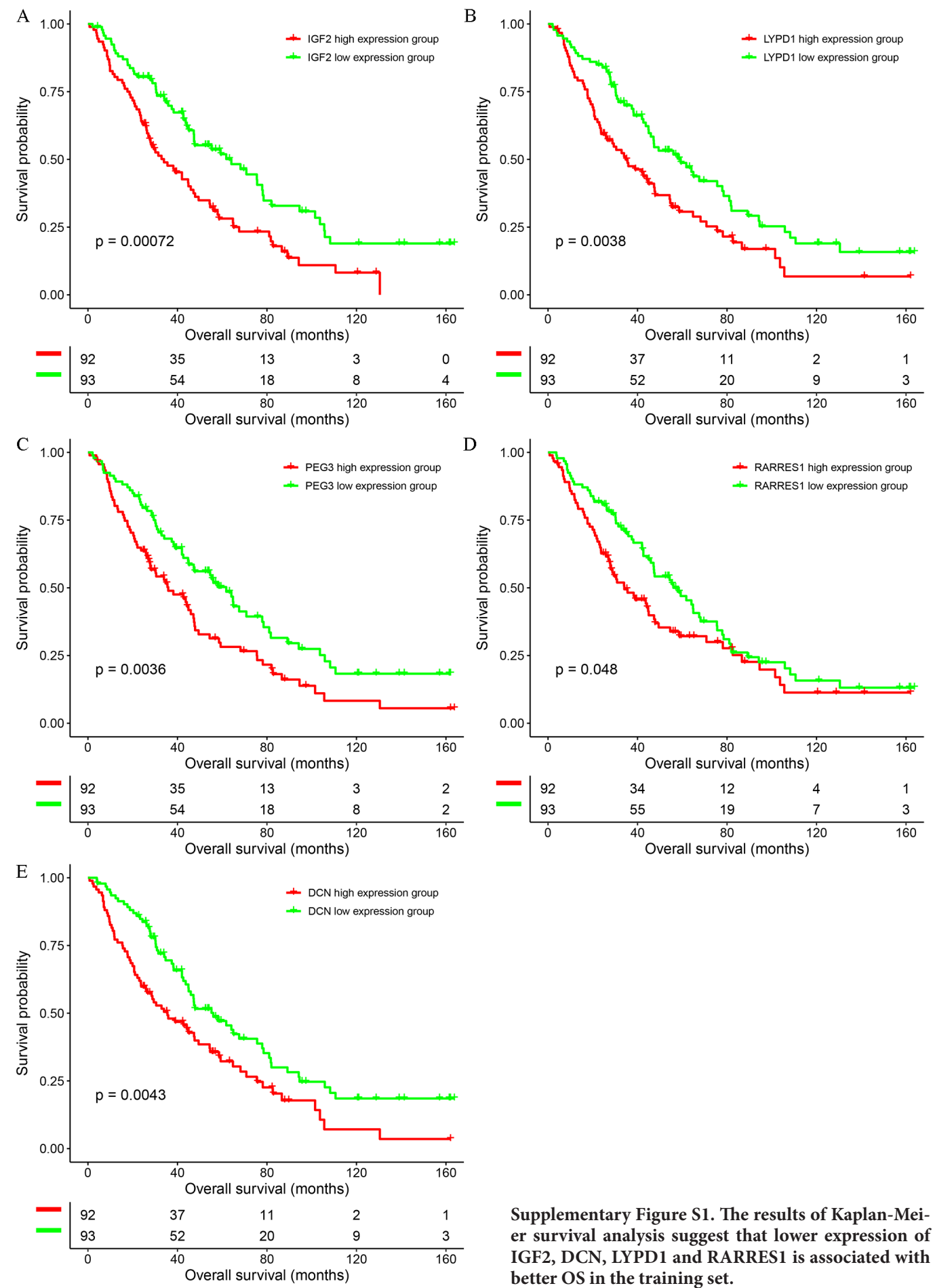

Supplementary Figure S1. The results of Kaplan-Meier survival analysis suggest that lower expression of IGF2, DCN, LYPD1 and RARRES1 is associated with better $O S$ in the training set. 

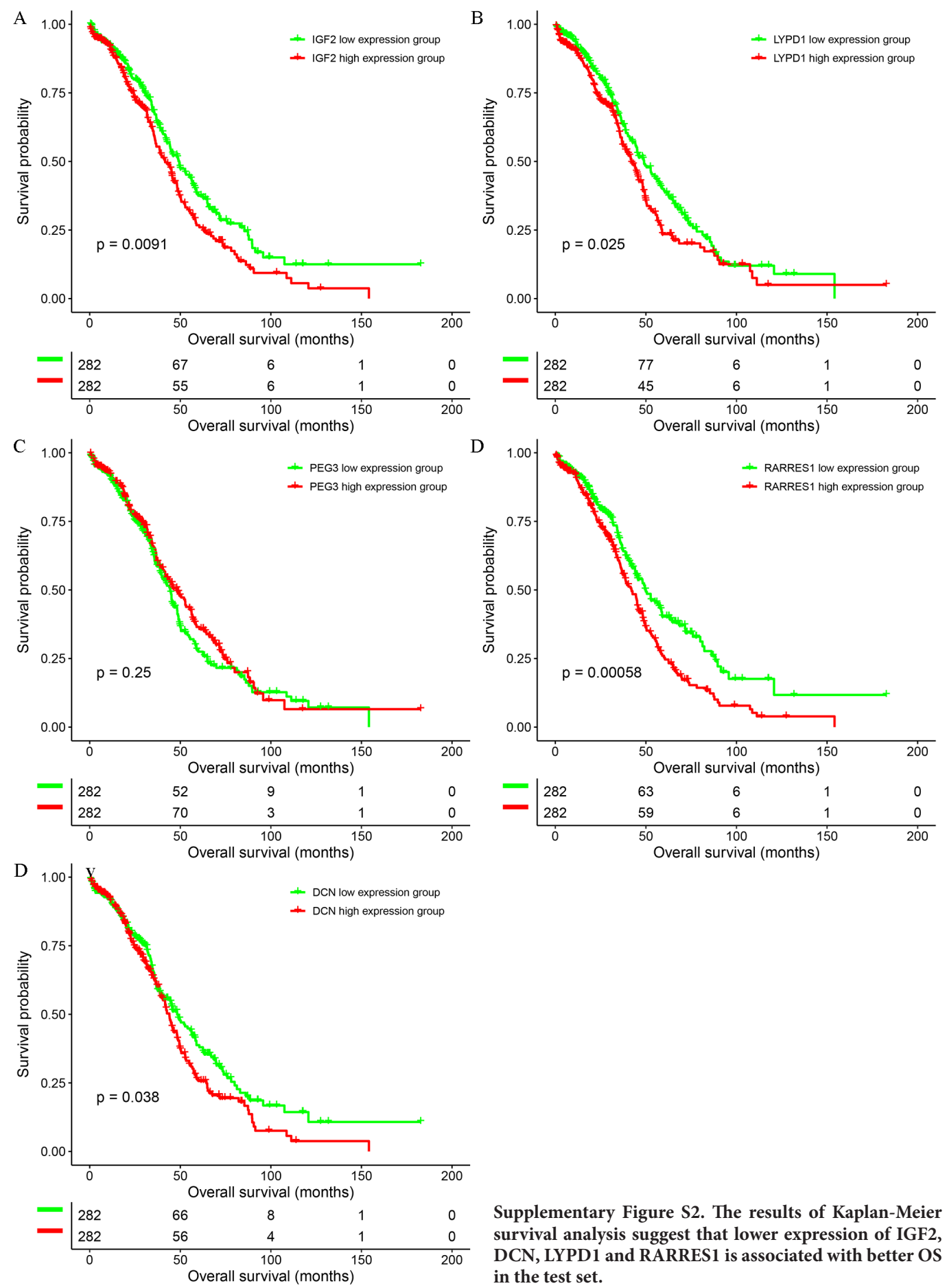

Supplementary Figure S2. The results of Kaplan-Meier survival analysis suggest that lower expression of IGF2, DCN, LYPD1 and RARRES1 is associated with better OS in the test set. 
Supplementary Table 1. 332 differentially expressed gene between normal ovary tissue and OC.

\begin{tabular}{|c|c|c|c|c|c|c|c|}
\hline Probe ID & Adjusted p-value & $\log \mathrm{FC}$ & Gene symbol & Probe ID & Adjusted p-value & $\log \mathrm{FC}$ & Gene symbol \\
\hline 204719_at & $2.22 \mathrm{E}-19$ & -4.16776 & ABCA8 & 200810_s_at & $1.48 \mathrm{E}-11$ & -2.16049 & CIRBP \\
\hline 201963_at & $2.52 \mathrm{E}-10$ & -2.25638 & ACSL1 & 204170_s_at & $4.29 \mathrm{E}-07$ & 2.362744 & CKS2 \\
\hline X00351_5_at & $8.42 \mathrm{E}-07$ & 2.660791 & ACTB & 219640_at & $1.21 \mathrm{E}-46$ & -2.25056 & CLDN15 \\
\hline 202381_at & $1.46 \mathrm{E}-12$ & -2.26269 & ADAM9 & 203953_s_at & $2.38 \mathrm{E}-12$ & 3.892081 & CLDN3 \\
\hline 214913_at & 4.12E-20 & -2.13792 & ADAMTS3 & 201428_at & $4.48 \mathrm{E}-12$ & 2.101791 & CLDN4 \\
\hline 212070_at & 5.27E-09 & 2.229783 & ADGRG1 & 207995_s_at & $5.18 \mathrm{E}-45$ & -2.51265 & CLEC4M \\
\hline 213094_at & $2.96 \mathrm{E}-14$ & -2.04628 & ADGRG6 & 213317_at & $6.69 \mathrm{E}-08$ & -2.60302 & CLIC5 \\
\hline 209613_s_at & $2.09 \mathrm{E}-11$ & -3.66243 & $\mathrm{ADH} 1 \mathrm{~B}$ & 214683_s_at & 3.62E-20 & -2.18401 & CLK1 \\
\hline 208848_at & $7.89 \mathrm{E}-11$ & -2.06097 & $\mathrm{ADH} 5$ & 202310_s_at & $2.05 \mathrm{E}-07$ & 3.226624 & COL1A1 \\
\hline 212224_at & $2.09 \mathrm{E}-12$ & -2.77912 & ALDH1A1 & 209156_s_at & $5.35 \mathrm{E}-04$ & 2.131939 & COL6A2 \\
\hline 222108_at & $2.01 \mathrm{E}-14$ & -2.79646 & AMIGO2 & 202110_at & $2.24 \mathrm{E}-09$ & 2.04221 & COX7B \\
\hline 206385_s_at & $2.08 \mathrm{E}-11$ & -2.0723 & ANK3 & 204846_at & 7.34E-08 & 2.329078 & $\mathrm{CP}$ \\
\hline 205206_at & $6.39 \mathrm{E}-14$ & -2.19893 & ANOS1 & 201116_s_at & $1.30 \mathrm{E}-12$ & -2.04869 & $\mathrm{CPE}$ \\
\hline 209369_at & $1.83 \mathrm{E}-13$ & -2.80928 & ANXA3 & 208146_s_at & $1.81 \mathrm{E}-13$ & -2.4312 & CPVL \\
\hline 203074_at & $1.10 \mathrm{E}-42$ & -3.40031 & ANXA8L1 & 202575_at & $9.49 \mathrm{E}-14$ & 3.312046 & CRABP2 \\
\hline 205083_at & $5.21 \mathrm{E}-34$ & -4.22561 & AOX1 & 201989_s_at & $8.59 \mathrm{E}-33$ & -2.42911 & CREBL2 \\
\hline 205568_at & $1.04 \mathrm{E}-29$ & -2.72917 & AQP9 & 219049_at & $8.42 \mathrm{E}-17$ & -2.31946 & CSGALNACT1 \\
\hline 213618_at & $1.25 \mathrm{E}-26$ & -2.207 & ARAP2 & 215121_x_at & $1.51 \mathrm{E}-03$ & 2.203539 & CYAT1 \\
\hline 205414_s_at & $3.48 \mathrm{E}-35$ & -2.23218 & ARHGAP44 & 203139_at & $1.62 \mathrm{E}-21$ & -2.24884 & DAPK1 \\
\hline 206167_s_at & $3.13 \mathrm{E}-20$ & -2.24395 & ARHGAP6 & 209335_at & $3.32 \mathrm{E}-05$ & -2.15118 & $\mathrm{DCN}$ \\
\hline 218694_at & 8.93E-30 & -3.45138 & ARMCX1 & 212855_at & 4.17E-36 & -2.02338 & DCUN1D4 \\
\hline 222103_at & $1.04 \mathrm{E}-13$ & -2.04397 & ATF1 & 213998_s_at & $2.24 \mathrm{E}-18$ & -2.88849 & DDX17 \\
\hline 201855_s_at & $2.78 \mathrm{E}-22$ & -2.09125 & ATMIN & 210397_at & $1.53 \mathrm{E}-04$ & 2.541294 & DEFB1 \\
\hline 213238_at & $3.75 \mathrm{E}-38$ & -2.27162 & ATP10D & 203695_s_at & $3.11 \mathrm{E}-43$ & -3.34069 & DFNA5 \\
\hline 209186_at & $8.59 \mathrm{E}-10$ & 2.002041 & ATP2A2 & 215506_s_at & $7.70 \mathrm{E}-16$ & -2.77867 & DIRAS3 \\
\hline 210149_s_at & $2.87 \mathrm{E}-14$ & 2.303593 & ATP5H & 201681_s_at & $4.79 \mathrm{E}-12$ & -2.02762 & DLG5 \\
\hline 213106_at & $1.13 \mathrm{E}-34$ & -2.32718 & ATP8A1 & 203881_s_at & $2.03 \mathrm{E}-17$ & -2.62651 & DMD \\
\hline 203232_s_at & $1.74 \mathrm{E}-18$ & -2.34824 & ATXN1 & 205003_at & $2.94 \mathrm{E}-12$ & -2.36394 & DOCK4 \\
\hline 203304_at & $3.14 \mathrm{E}-11$ & -2.0492 & BAMBI & 204646_at & 4.17E-27 & -3.72056 & DPYD \\
\hline 203009_at & 7.69E-10 & 2.000145 & BCAM & 200762_at & $4.68 \mathrm{E}-12$ & -2.54164 & DPYSL2 \\
\hline 205433_at & 3.32E-32 & -4.43005 & BCHE & 206032_at & $2.22 \mathrm{E}-38$ & -2.26127 & DSC3 \\
\hline 201545_s_at & $1.19 \mathrm{E}-17$ & 2.187724 & PABPN1 & 218854_at & $1.09 \mathrm{E}-21$ & -3.07949 & DSE \\
\hline 213429_at & $1.44 \mathrm{E}-18$ & -2.1286 & BICC1 & 206101_at & $7.51 \mathrm{E}-18$ & -2.56347 & ECM2 \\
\hline 206581_at & 3.33E-79 & -3.72993 & BNC1 & 201843_s_at & $6.58 \mathrm{E}-24$ & -3.89742 & EFEMP1 \\
\hline 209430_at & $7.98 \mathrm{E}-31$ & -2.74434 & BTAF1 & 219833_s_at & 7.12E-18 & -2.08989 & EFHC1 \\
\hline 219010_at & $1.52 \mathrm{E}-11$ & 2.059427 & C1orf106 & 210827_s_at & $3.69 \mathrm{E}-13$ & 2.621677 & ELF3 \\
\hline 220543_at & $9.76 \mathrm{E}-40$ & -2.11256 & C21orf62 & 217294_s_at & $3.83 \mathrm{E}-04$ & 2.044274 & ENO1 \\
\hline 204480_s_at & $6.63 \mathrm{E}-25$ & 2.809954 & C9orf16 & 217886_at & $9.18 \mathrm{E}-25$ & -2.03626 & EPS15 \\
\hline 205428_s_at & $9.23 \mathrm{E}-39$ & -3.89844 & CALB2 & 217234_s_at & $4.96 \mathrm{E}-17$ & -2.01056 & EZR \\
\hline 200935_at & $2.71 \mathrm{E}-13$ & 2.3752 & CALR & 218518_at & $3.42 \mathrm{E}-24$ & -2.76031 & FAM13B \\
\hline 212586_at & $9.33 \mathrm{E}-15$ & -2.48788 & CAST & 215000_s_at & 4.12E-20 & -2.38943 & FEZ2 \\
\hline 212097_at & $3.15 \mathrm{E}-11$ & -2.86996 & CAV1 & 205110_s_at & $4.69 \mathrm{E}-37$ & -2.75939 & FGF13 \\
\hline 203324_s_at & $1.07 \mathrm{E}-11$ & -2.07008 & CAV2 & 206404_at & $6.00 \mathrm{E}-13$ & -2.4197 & FGF9 \\
\hline 216379_x_at & $3.06 \mathrm{E}-20$ & 4.345562 & $\mathrm{CD} 24$ & 219250_s_at & $3.70 \mathrm{E}-13$ & -2.26279 & FLRT3 \\
\hline 202870_s_at & $9.16 \mathrm{E}-08$ & 2.068895 & CDC20 & 204437_s_at & $1.83 \mathrm{E}-11$ & 3.4742 & FOLR1 \\
\hline 202156_s_at & $1.76 \mathrm{E}-23$ & -2.1972 & CELF2 & 213056_at & $1.17 \mathrm{E}-25$ & -2.72701 & FRMD4B \\
\hline 213800_at & $4.63 \mathrm{E}-10$ & -2.26546 & $\mathrm{CFH}$ & 204072_s_at & $6.93 \mathrm{E}-34$ & -3.10251 & FRY \\
\hline 215388_s_at & $9.63 \mathrm{E}-11$ & -2.35194 & CFHR1 & 202489_s_at & $2.68 \mathrm{E}-07$ & 2.127299 & FXYD3 \\
\hline 203854_at & $3.66 \mathrm{E}-14$ & -2.58878 & CFI & 203706_s_at & $1.38 \mathrm{E}-10$ & -2.23584 & FZD7 \\
\hline 204260_at & $7.66 \mathrm{E}-25$ & -2.07391 & CHGB & 211458_s_at & 4.47E-10 & -2.26778 & GABARAPL3 \\
\hline 202536_at & $4.04 \mathrm{E}-12$ & -2.0542 & СНMP2B & 204417_at & $1.68 \mathrm{E}-20$ & -2.33445 & GALC \\
\hline 218085_at & $8.37 \mathrm{E}-11$ & -2.0057 & CHMP5 & 218885_s_at & $9.83 \mathrm{E}-24$ & -2.1412 & GALNT12 \\
\hline 209763_at & $9.74 \mathrm{E}-23$ & -3.61456 & CHRDL1 & 204457_s_at & $6.78 \mathrm{E}-11$ & -2.7071 & GAS1 \\
\hline
\end{tabular}


R. WANG, X. H. YE, X. L. ZHAO, J. L. LIU, C. Y. ZHANG

Supplementary Table 1. Continued

\begin{tabular}{|c|c|c|c|c|c|c|c|}
\hline Probe ID & Adjusted p-value & $\log \mathrm{FC}$ & Gene symbol & Probe ID & Adjusted p-value & $\log \mathrm{FC}$ & Gene symbol \\
\hline 210002_at & $4.53 \mathrm{E}-10$ & -2.86424 & GATA6 & 201505_at & 3.82E-09 & -2.23483 & LAMB1 \\
\hline 203765_at & $3.77 \mathrm{E}-19$ & -2.33892 & GCA & 212531_at & $4.83 \mathrm{E}-06$ & 2.597947 & LCN2 \\
\hline 212244_at & $3.76 \mathrm{E}-32$ & -2.32237 & GCOM1 & 208450_at & $1.10 \mathrm{E}-22$ & -2.19929 & LGALS2 \\
\hline 205100_at & $2.23 \mathrm{E}-23$ & -2.24551 & GFPT2 & 208933_s_at & $4.13 \mathrm{E}-36$ & -3.35962 & LGALS8 \\
\hline 205498_at & $7.36 \mathrm{E}-18$ & -2.52147 & GHR & 206140_at & $1.32 \mathrm{E}-40$ & -3.75029 & LHX2 \\
\hline 201667_at & $1.22 \mathrm{E}-04$ & -2.04991 & GJA1 & 201847_at & $1.47 \mathrm{E}-08$ & -2.0862 & LIPA \\
\hline 203159_at & $6.62 \mathrm{E}-28$ & -2.09898 & GLS & 200772_x_at & 7.63E-16 & 2.162312 & PTMA \\
\hline 204115_at & 3.97E-10 & -2.14425 & GNG11 & 204359_at & $5.87 \mathrm{E}-22$ & -4.00834 & FLRT2 \\
\hline 209469_at & $2.01 \mathrm{E}-62$ & -3.85864 & GPM6A & 201278_at & $5.57 \mathrm{E}-28$ & -2.89922 & $\mathrm{DAB} 2$ \\
\hline 204137_at & $7.44 \mathrm{E}-20$ & -2.15283 & GPR137B & 207016_s_at & $1.02 \mathrm{E}-32$ & -4.36511 & ALDH1A2 \\
\hline 204793_at & $1.56 \mathrm{E}-14$ & -2.31537 & GPRASP1 & 222281_s_at & $1.99 \mathrm{E}-12$ & 3.880707 & C1orf186 \\
\hline 205862_at & $2.10 \mathrm{E}-15$ & -2.69417 & GREB1 & 202551_s_at & $7.80 \mathrm{E}-12$ & -2.11329 & CRIM1 \\
\hline 212090_at & $2.01 \mathrm{E}-16$ & 2.174916 & GRINA & 214945_at & $1.16 \mathrm{E}-54$ & -4.66198 & LOC101930363 \\
\hline 222150_s_at & $1.77 \mathrm{E}-26$ & -2.40013 & GSAP & 202736_s_at & $3.45 \mathrm{E}-08$ & 2.220243 & LSM4 \\
\hline 200824_at & $3.94 \mathrm{E}-20$ & 2.442904 & GSTP1 & 208835_s_at & $6.66 \mathrm{E}-10$ & -2.23185 & LUC7L3 \\
\hline 205436_s_at & $5.25 \mathrm{E}-15$ & 2.294294 & $\mathrm{H} 2 \mathrm{AFX}$ & 218729_at & $2.14 \mathrm{E}-11$ & -2.48403 & LXN \\
\hline 208579_x_at & $1.40 \mathrm{E}-09$ & 2.404874 & H2BFS & 212909_at & $2.41 \mathrm{E}-05$ & 2.098813 & LYPD1 \\
\hline 207316_at & $3.81 \mathrm{E}-15$ & -2.02722 & HAS1 & 209348_s_at & $2.63 \mathrm{E}-30$ & -3.18447 & MAF \\
\hline 214414_x_at & $1.50 \mathrm{E}-07$ & -3.57167 & HBA2 & 205027_s_at & $1.02 \mathrm{E}-32$ & -2.15682 & MAP3K8 \\
\hline 209116_x_at & 4.03E-08 & -4.09804 & HBB & 205819_at & $5.91 \mathrm{E}-22$ & -2.70494 & MARCO \\
\hline 213515_x_at & $8.43 \mathrm{E}-20$ & -2.45235 & HBG2 & 209035_at & $3.04 \mathrm{E}-06$ & 2.026546 & MDK \\
\hline 213069_at & $7.70 \mathrm{E}-22$ & -3.1479 & HEG1 & 204059_s_at & $5.74 \mathrm{E}-31$ & -2.27797 & ME1 \\
\hline 209398_at & $3.51 \mathrm{E}-06$ & 2.025838 & HIST1H1C & 221884_at & 7.17E-14 & 2.87032 & MECOM \\
\hline 214290_s_at & $9.29 \mathrm{E}-17$ & 3.813299 & HIST2H2AA4 & 209200_at & $2.34 \mathrm{E}-15$ & -2.01228 & MEF2C \\
\hline 206074_s_at & $1.15 \mathrm{E}-13$ & 2.469522 & HMGA1 & 207480_s_at & $2.50 \mathrm{E}-22$ & -3.05219 & MEIS2 \\
\hline 221480_at & $2.23 \mathrm{E}-57$ & -2.14345 & HNRNPD & 203510_at & $6.90 \mathrm{E}-22$ & -3.20603 & MET \\
\hline 206858_s_at & $5.97 \mathrm{E}-19$ & -2.64051 & HOXC6 & 207761_s_at & $1.21 \mathrm{E}-12$ & -2.55681 & METTL7A \\
\hline 206697_s_at & $1.24 \mathrm{E}-06$ & -2.75649 & HP & 217756_x_at & $1.04 \mathrm{E}-17$ & 2.010399 & SERF2 \\
\hline 208470_s_at & $5.52 \mathrm{E}-05$ & -2.18991 & HPR & 214696_at & $1.07 \mathrm{E}-15$ & -2.36434 & MIR22HG \\
\hline 217989_at & $3.76 \mathrm{E}-11$ & -2.02168 & HSD17B11 & 203189_s_at & $2.81 \mathrm{E}-12$ & 2.195696 & NDUFS8 \\
\hline 201655_s_at & $1.79 \mathrm{E}-12$ & 2.096271 & HSPG2 & 211430_s_at & $1.29 \mathrm{E}-02$ & 2.369659 & IGHG1 \\
\hline 209292_at & $1.74 \mathrm{E}-10$ & -2.82513 & ID4 & 203878_s_at & $2.79 \mathrm{E}-06$ & 2.216431 & MMP11 \\
\hline 210046_s_at & $8.51 \mathrm{E}-10$ & 2.058312 & IDH2 & 204259_at & $3.57 \mathrm{E}-04$ & 2.159356 & MMP7 \\
\hline 202411_at & $1.39 \mathrm{E}-04$ & 2.038914 & IFI27 & 204959_at & $5.44 \mathrm{E}-55$ & -4.43974 & MNDA \\
\hline 204415_at & $8.26 \mathrm{E}-06$ & 2.053799 & IFI6 & 204331_s_at & 4.64E-06 & 2.088749 & MRPS12 \\
\hline 202718_at & $3.15 \mathrm{E}-15$ & 3.881271 & IGFBP2 & 212096_s_at & $5.40 \mathrm{E}-19$ & -2.46268 & MTUS1 \\
\hline 203851_at & $2.67 \mathrm{E}-11$ & -2.28862 & IGFBP6 & 213693_s_at & $8.79 \mathrm{E}-10$ & 2.910366 & MUC1 \\
\hline 217022_s_at & $3.87 \mathrm{E}-03$ & 2.3252 & IGHA2 & 221899_at & $5.72 \mathrm{E}-17$ & -2.8265 & N4BP2L2 \\
\hline 214677_x_at & $5.70 \mathrm{E}-03$ & 2.574819 & IGLC1 & 204749_at & $1.43 \mathrm{E}-30$ & -3.28136 & NAP1L3 \\
\hline 215379_x_at & $3.50 \mathrm{E}-03$ & 2.064311 & IGLV1-44 & 33767_at & $3.74 \mathrm{E}-11$ & -2.06774 & NEFH \\
\hline 212195_at & $1.03 \mathrm{E}-09$ & -2.74261 & IL6ST & 203413_at & $6.56 \mathrm{E}-61$ & -3.68444 & NELL2 \\
\hline 202409_at & $3.42 \mathrm{E}-03$ & 2.47873 & IGF2 & 209706_at & $5.86 \mathrm{E}-48$ & -2.57723 & NKX3-1 \\
\hline 205483_s_at & $9.44 \mathrm{E}-07$ & 2.450106 & ISG15 & 203238_s_at & $7.72 \mathrm{E}-20$ & 2.764711 & NOTCH3 \\
\hline 218170_at & $3.77 \mathrm{E}-15$ & -2.15637 & ISOC1 & 205440_s_at & $6.13 \mathrm{E}-54$ & -3.67194 & NPY1R \\
\hline 205786_s_at & $2.57 \mathrm{E}-23$ & -2.26522 & ITGAM & 209505_at & $2.25 \mathrm{E}-13$ & -2.69013 & NR2F1 \\
\hline 201473_at & $6.57 \mathrm{E}-08$ & 2.126389 & JUNB & 209120_at & $1.31 \mathrm{E}-06$ & -2.05081 & NR2F2 \\
\hline 203845_at & $6.05 \mathrm{E}-20$ & -2.11657 & KAT2B & 209570_s_at & $9.15 \mathrm{E}-14$ & -2.55553 & NSG1 \\
\hline 200922_at & $1.46 \mathrm{E}-12$ & 2.028977 & KDELR1 & 222203_s_at & $8.05 \mathrm{E}-25$ & -2.16961 & RDH14 \\
\hline 203934_at & $1.16 \mathrm{E}-72$ & -3.11676 & KDR & 218051_s_at & $5.54 \mathrm{E}-10$ & 2.135175 & NT5DC2 \\
\hline 221841_s_at & $7.46 \mathrm{E}-06$ & -2.22342 & KLF4 & 218730_s_at & $1.46 \mathrm{E}-15$ & -2.36917 & OGN \\
\hline 204733_at & $2.69 \mathrm{E}-08$ & 2.560931 & KLK6 & 217525_at & $2.94 \mathrm{E}-22$ & -2.44233 & OLFML1 \\
\hline 206125_s_at & $1.41 \mathrm{E}-09$ & 2.031964 & KLK8 & 209552_at & $2.55 \mathrm{E}-11$ & 2.121913 & PAX8 \\
\hline 202202_s_at & $4.57 \mathrm{E}-17$ & -2.71428 & LAMA4 & 218515_at & $9.15 \mathrm{E}-25$ & -2.0084 & PAXBP1 \\
\hline
\end{tabular}


Supplementary Table 1. Continued

\begin{tabular}{|c|c|c|c|}
\hline Probe ID & Adjusted p-value & $\log \mathrm{FC}$ & Gene symbol \\
\hline 219737_s_at & $4.26 \mathrm{E}-35$ & -2.20263 & PCDH9 \\
\hline 219295_s_at & $1.16 \mathrm{E}-22$ & -2.22582 & PCOLCE2 \\
\hline 213228_at & $1.14 \mathrm{E}-36$ & -2.39896 & PDE8B \\
\hline 218718_at & $9.41 \mathrm{E}-12$ & -2.39503 & PDGFC \\
\hline 219304_s_at & $2.64 \mathrm{E}-20$ & -2.99789 & PDGFD \\
\hline 221898_at & $5.78 \mathrm{E}-22$ & -2.14319 & PDPN \\
\hline 209493_at & $1.16 \mathrm{E}-12$ & -2.04241 & PDZD2 \\
\hline 200787_s_at & $8.52 \mathrm{E}-15$ & 2.252569 & PEA15 \\
\hline 209242_at & $1.54 \mathrm{E}-06$ & -3.1553 & PEG3 \\
\hline 200634_at & $9.36 \mathrm{E}-20$ & 3.398226 & PFN1 \\
\hline 213227_at & $1.32 \mathrm{E}-21$ & -2.26637 & PGRMC2 \\
\hline 204049_s_at & $6.51 \mathrm{E}-27$ & -2.42175 & PHACTR2 \\
\hline 203688_at & $1.14 \mathrm{E}-15$ & -2.20414 & PKD2 \\
\hline 201251_at & $1.99 \mathrm{E}-19$ & 3.262371 & PKM \\
\hline 213222_at & $4.75 \mathrm{E}-10$ & -2.05202 & PLCB1 \\
\hline 205111_s_at & $4.88 \mathrm{E}-39$ & -2.22766 & PLCE1 \\
\hline 209122_at & $3.42 \mathrm{E}-09$ & -2.01881 & PLIN2 \\
\hline 210946_at & $2.25 \mathrm{E}-24$ & -2.90344 & PLPP1 \\
\hline 218901_at & $6.27 \mathrm{E}-26$ & -3.39253 & PLSCR4 \\
\hline 212179_at & $2.09 \mathrm{E}-20$ & -2.42237 & PNISR \\
\hline 217779_s_at & $1.24 \mathrm{E}-18$ & -2.03972 & PNRC2 \\
\hline 201578_at & $9.28 \mathrm{E}-11$ & -2.18479 & PODXL \\
\hline 218010_x_at & $2.74 \mathrm{E}-24$ & 2.918798 & PPDPF \\
\hline 212215_at & $2.59 \mathrm{E}-21$ & -2.16514 & PREPL \\
\hline 206007_at & $9.61 \mathrm{E}-47$ & -2.95447 & PRG4 \\
\hline 200603_at & $1.50 \mathrm{E}-12$ & -2.24346 & PRKAR1A \\
\hline 203680_at & $1.92 \mathrm{E}-11$ & -2.13829 & PRKAR2B \\
\hline 200707_at & $3.24 \mathrm{E}-11$ & 2.19688 & PRKCSH \\
\hline 206445_s_at & $1.00 \mathrm{E}-16$ & 2.226572 & PRMT1 \\
\hline 201300_s_at & 8.02E-08 & -2.0224 & PRNP \\
\hline 203650_at & $5.92 \mathrm{E}-41$ & -3.47704 & PROCR \\
\hline 207808_s_at & $4.22 \mathrm{E}-22$ & -3.3456 & PROS1 \\
\hline 202525_at & $1.07 \mathrm{E}-09$ & 2.003049 & PRSS8 \\
\hline 203355_s_at & $1.95 \mathrm{E}-52$ & -3.31581 & PSD3 \\
\hline 213933_at & $7.43 \mathrm{E}-20$ & -2.30298 & PTGER3 \\
\hline 204897_at & $3.90 \mathrm{E}-15$ & -2.68542 & PTGER4 \\
\hline 208131_s_at & $6.30 \mathrm{E}-09$ & -2.60326 & PTGIS \\
\hline 212588_at & $1.55 \mathrm{E}-10$ & -2.16582 & PTPRC \\
\hline 204020_at & $5.67 \mathrm{E}-14$ & -2.09451 & PURA \\
\hline 212636_at & $1.35 \mathrm{E}-16$ & -2.5737 & QKI \\
\hline 218668_s_at & $1.48 \mathrm{E}-20$ & -2.29864 & RAP2C \\
\hline 221872_at & $3.42 \mathrm{E}-06$ & -2.62375 & RARRES1 \\
\hline 212027_at & $9.36 \mathrm{E}-14$ & -2.29353 & RBM25 \\
\hline 205407_at & $1.08 \mathrm{E}-22$ & -2.3872 & RECK \\
\hline 204364_s_at & $2.61 \mathrm{E}-53$ & -3.94761 & REEP1 \\
\hline 204337_at & $1.56 \mathrm{E}-16$ & -2.86813 & RGS4 \\
\hline 212099_at & $1.88 \mathrm{E}-09$ & 2.6548 & RHOB \\
\hline 218323_at & $3.42 \mathrm{E}-25$ & -2.08571 & RHOT1 \\
\hline 213397_x_at & $5.32 \mathrm{E}-16$ & -2.92585 & RNASE4 \\
\hline 214041_x_at & $1.19 \mathrm{E}-21$ & 3.167255 & RPL37A \\
\hline 200082_s_at & $4.05 \mathrm{E}-18$ & 3.064104 & RPS7 \\
\hline 209006_s_at & $8.53 \mathrm{E}-27$ & -2.77715 & RSRP1 \\
\hline 203485_at & $1.85 \mathrm{E}-30$ & -2.94876 & RTN1 \\
\hline
\end{tabular}

\begin{tabular}{|c|c|c|c|}
\hline Probe ID & Adjusted p-value & $\log \mathrm{FC}$ & Gene symbol \\
\hline 200660_at & $1.99 \mathrm{E}-11$ & 2.556766 & S100A11 \\
\hline 202598_at & $9.60 \mathrm{E}-17$ & 2.6354 & S100A13 \\
\hline 204268_at & $2.21 \mathrm{E}-06$ & 2.405757 & S100A2 \\
\hline 217728_at & $5.21 \mathrm{E}-11$ & 2.222818 & S100A6 \\
\hline 218370_s_at & $4.87 \mathrm{E}-44$ & -2.25463 & S100PBP \\
\hline 200847_s_at & $1.83 \mathrm{E}-13$ & -2.38721 & SARAF \\
\hline 203889_at & $2.03 \mathrm{E}-11$ & -2.75873 & SCG5 \\
\hline 205979_at & $1.76 \mathrm{E}-06$ & 3.591818 & SCGB2A1 \\
\hline 201339_s_at & $1.72 \mathrm{E}-07$ & -2.01388 & SCP2 \\
\hline 212314_at & $2.82 \mathrm{E}-16$ & -2.15107 & SEL1L3 \\
\hline 203789_s_at & 2.41E-09 & -2.5231 & SEMA3C \\
\hline 213169_at & $2.26 \mathrm{E}-25$ & -2.26337 & SEMA5A \\
\hline 209723_at & $1.05 \mathrm{E}-16$ & -2.13449 & SERPINB9 \\
\hline 215780_s_at & $4.75 \mathrm{E}-09$ & 2.208081 & SET \\
\hline 202037_s_at & $4.56 \mathrm{E}-16$ & -3.1809 & SFRP1 \\
\hline 202234_s_at & $4.57 \mathrm{E}-24$ & -2.55208 & SLC16A1 \\
\hline 219215_s_at & $1.65 \mathrm{E}-09$ & 2.042175 & SLC39A4 \\
\hline 209267_s_at & $2.39 \mathrm{E}-23$ & -3.62037 & SLC39A8 \\
\hline 214719_at & $9.64 \mathrm{E}-42$ & -2.44201 & SLC46A3 \\
\hline 203908_at & $1.26 \mathrm{E}-54$ & -3.67051 & SLC4A4 \\
\hline 222155_s_at & $7.00 \mathrm{E}-12$ & 2.592536 & SLC52A2 \\
\hline 206874_s_at & $4.76 \mathrm{E}-18$ & -2.3195 & SLK \\
\hline 217707_x_at & $1.12 \mathrm{E}-12$ & -2.39091 & SMARCA2 \\
\hline 219511_s_at & $8.38 \mathrm{E}-28$ & -2.69503 & SNCAIP \\
\hline 200869_at & $3.98 \mathrm{E}-28$ & 4.120789 & RPL18A \\
\hline 213704_at & $1.26 \mathrm{E}-20$ & -2.18703 & RABGGTB \\
\hline 205573_s_at & $2.33 \mathrm{E}-14$ & -2.15827 & SNX7 \\
\hline 218974_at & $5.47 \mathrm{E}-12$ & -2.26683 & SOBP \\
\hline 219993_at & $1.06 \mathrm{E}-15$ & 3.07392 & SOX17 \\
\hline 202936_s_at & $5.41 \mathrm{E}-12$ & 2.21883 & SOX9 \\
\hline 202363_at & $4.65 \mathrm{E}-37$ & -3.20397 & SPOCK1 \\
\hline 218499_at & $1.05 \mathrm{E}-39$ & -3.97485 & STK26 \\
\hline 212353_at & $1.58 \mathrm{E}-07$ & -2.52873 & SULF1 \\
\hline 200911_s_at & $2.89 \mathrm{E}-14$ & -2.55058 & TACC1 \\
\hline 205547_s_at & $1.27 \mathrm{E}-05$ & 2.423051 & TAGLN \\
\hline 211276_at & $4.89 \mathrm{E}-22$ & -4.06643 & TCEAL2 \\
\hline 204931_at & $1.59 \mathrm{E}-13$ & -2.3008 & TCF21 \\
\hline 209277_at & $4.74 \mathrm{E}-41$ & -3.06902 & TFPI2 \\
\hline 202085_at & $1.98 \mathrm{E}-11$ & -2.06054 & TJP2 \\
\hline 204872_at & $5.30 \mathrm{E}-16$ & -2.38261 & TLE4 \\
\hline 204427_s_at & $4.47 \mathrm{E}-06$ & 2.005576 & TMED2 \\
\hline 219895_at & $5.40 \mathrm{E}-56$ & -3.32769 & TMEM255A \\
\hline 201581_at & $2.06 \mathrm{E}-17$ & -2.7922 & TMX4 \\
\hline 202704_at & 7.51E-09 & -2.14785 & TOB1 \\
\hline 203786_s_at & $3.05 \mathrm{E}-19$ & -2.39369 & TPD52L1 \\
\hline 205803_s_at & $1.24 \mathrm{E}-28$ & -2.47603 & TRPC1 \\
\hline 217979_at & $2.13 \mathrm{E}-12$ & -2.34475 & TSPAN13 \\
\hline 203824_at & $1.10 \mathrm{E}-07$ & -2.26876 & TSPAN8 \\
\hline 221493_at & $2.73 \mathrm{E}-12$ & -2.1582 & TSPYL1 \\
\hline 202954_at & $3.27 \mathrm{E}-13$ & 2.116956 & UBE2C \\
\hline 208998_at & 4.92E-07 & 2.01738 & UCP2 \\
\hline 218449_at & $3.47 \mathrm{E}-24$ & -2.37212 & UFSP2 \\
\hline 206658_at & $5.85 \mathrm{E}-06$ & -2.15834 & UPK3B \\
\hline
\end{tabular}


Supplementary Table 1. Continued

\begin{tabular}{lccc}
\hline Probe ID & Adjusted p-value & $\operatorname{logFC}$ & Gene symbol \\
\hline 201568_at & $2.24 \mathrm{E}-10$ & 2.09715 & UQCRQ \\
218396_at & $4.06 \mathrm{E}-15$ & -2.05476 & VPS13C \\
203892_at & $7.53 \mathrm{E}-16$ & 3.604279 & WFDC2 \\
206458_s_at & $7.11 \mathrm{E}-42$ & -2.66765 & WNT2B \\
213425_at & $2.59 \mathrm{E}-32$ & -2.78657 & WNT5A \\
201294_s_at & $2.93 \mathrm{E}-28$ & -2.29403 & WSB1 \\
206067_s_at & $1.66 \mathrm{E}-09$ & -2.10521 & WT1 \\
210996_s_at & $1.47 \mathrm{E}-13$ & 2.28527 & YWHAE \\
213156_at & $2.99 \mathrm{E}-15$ & -2.27837 & ZBTB20 \\
212982_at & $1.24 \mathrm{E}-23$ & -2.2579 & ZDHHC17 \\
219778_at & $4.63 \mathrm{E}-09$ & -2.75905 & ZFPM2 \\
209814_at & $5.51 \mathrm{E}-27$ & -2.677 & ZNF330 \\
222028_at & $5.81 \mathrm{E}-39$ & -2.07903 & ZNF45 \\
204175_at & $7.25 \mathrm{E}-13$ & 2.08818 & ZNF593 \\
\hline
\end{tabular}

Supplementary Table 2. DEGs that were significantly correlated with the overall survival of OC patients.

\begin{tabular}{lcccc}
\hline Gene Symbol & HR & LCI & UCI & p-value \\
\hline IGF2 & 1.155904 & 1.077828 & 1.239634 & $4.90 \mathrm{E}-05$ \\
RECK & 1.692166 & 1.308165 & 2.188887 & $6.19 \mathrm{E}-05$ \\
PTGER3 & 1.687189 & 1.293083 & 2.201411 & $1.16 \mathrm{E}-04$ \\
PHACTR2 & 1.648691 & 1.255291 & 2.16538 & $3.25 \mathrm{E}-04$ \\
PSD3 & 1.853413 & 1.305842 & 2.630593 & $5.53 \mathrm{E}-04$ \\
GPRASP1 & 1.374989 & 1.145661 & 1.65022 & $6.25 \mathrm{E}-04$ \\
PDGFD & 1.335095 & 1.122146 & 1.588455 & 0.001115 \\
ABCA8 & 1.244154 & 1.09064 & 1.419277 & 0.001149 \\
PDE8B & 1.850172 & 1.275062 & 2.684682 & 0.001198 \\
DCN & 1.216478 & 1.080111 & 1.37006 & 0.001236 \\
ECM2 & 1.367841 & 1.128223 & 1.658349 & 0.001434 \\
GFPT2 & 1.60216 & 1.196773 & 2.144866 & 0.001541 \\
KDR & 2.496187 & 1.38058 & 4.513284 & 0.002468 \\
EFEMP1 & 1.259244 & 1.081612 & 1.46605 & 0.002967 \\
CHGN & 1.328542 & 1.095567 & 1.611061 & 0.00388 \\
HOXC6 & 1.346405 & 1.09994 & 1.648096 & 0.003934 \\
ALDH1A2 & 1.275981 & 1.079367 & 1.508409 & 0.00431 \\
C6ORF111 & 1.426383 & 1.116916 & 1.821593 & 0.004426 \\
ALDH1A1 & 1.227977 & 1.064256 & 1.416885 & 0.004909 \\
CAV2 & 1.337283 & 1.091337 & 1.638657 & 0.005065 \\
PDPN & 1.512641 & 1.126845 & 2.030523 & 0.005871 \\
MEF2C & 1.422748 & 1.105835 & 1.830484 & 0.006099 \\
LOC653754 & 1.658216 & 1.154323 & 2.38207 & 0.00621 \\
RHOT1 & 1.568865 & 1.135197 & 2.168202 & 0.00637 \\
LYPD1 & 0.836817 & 0.735941 & 0.951521 & 0.006564 \\
RARRES1 & 1.157035 & 1.04117 & 1.285793 & 0.006741 \\
NAP1L3 & 1.311493 & 1.074959 & 1.600075 & 0.007534 \\
FLJ10159 & 1.295373 & 1.069451 & 1.569022 & 0.00813 \\
SNCAIP & 1.421542 & 1.092331 & 1.849971 & 0.00887 \\
ADH1B & 1.176641 & 1.041035 & 1.329911 & 0.009223 \\
PEG3 & 1.124622 & 1.028839 & 1.229323 & 0.009711 \\
BAMBI & 1.275562 & 1.060642 & 1.534031 & 0.009728 \\
\hline & & & &
\end{tabular}

\begin{tabular}{lcccc}
\hline Gene Symbol & HR & LCI & UCI & p-value \\
\hline CAV1 & 1.2066 & 1.046258 & 1.391516 & 0.009836 \\
FZD7 & 1.266187 & 1.058346 & 1.514845 & 0.009885 \\
ARHGAP6 & 1.40526 & 1.083322 & 1.822872 & 0.010382 \\
NR2F2 & 1.211887 & 1.046241 & 1.40376 & 0.010384 \\
OLFML1 & 1.322555 & 1.064904 & 1.642543 & 0.011446 \\
IFI27 & 0.86593 & 0.773997 & 0.968784 & 0.011945 \\
D4S234E & 0.789259 & 0.656001 & 0.949586 & 0.012135 \\
FLRT2 & 1.210822 & 1.040809 & 1.408606 & 0.013208 \\
ADH1B & 1.156958 & 1.030396 & 1.299065 & 0.013643 \\
MTUS1 & 1.309358 & 1.056877 & 1.622154 & 0.013659 \\
GALC & 1.370127 & 1.06575 & 1.761433 & 0.014019 \\
PPAP2A & 1.361571 & 1.063615 & 1.742995 & 0.014309 \\
NR2F1 & 1.222508 & 1.039093 & 1.438298 & 0.015421 \\
RHOB & 1.18208 & 1.028311 & 1.358843 & 0.018643 \\
H2BFS & 0.830951 & 0.710199 & 0.972233 & 0.020808 \\
SLC39A4 & 0.818461 & 0.690484 & 0.970158 & 0.020933 \\
GALNT12 & 0.685402 & 0.496802 & 0.9456 & 0.021413 \\
RNASE4 & 1.212845 & 1.028974 & 1.429573 & 0.021422 \\
SEMA3C & 1.180876 & 1.024728 & 1.360817 & 0.021589 \\
LAMA4 & 1.278289 & 1.03396 & 1.580354 & 0.023297 \\
LOC283537 & 1.60001 & 1.064437 & 2.405058 & 0.023805 \\
CIRBP & 1.263725 & 1.028987 & 1.552012 & 0.025581 \\
DOCK4 & 1.212601 & 1.022502 & 1.438043 & 0.026709 \\
ADH5 & 1.245144 & 1.023108 & 1.515367 & 0.028674 \\
LAMB1 & 1.212653 & 1.019134 & 1.442919 & 0.029733 \\
MAF & 1.301021 & 1.022468 & 1.655462 & 0.032297 \\
ACSL1 & 1.220492 & 1.01449 & 1.468325 & 0.034645 \\
IGFBP6 & 1.214964 & 1.01361 & 1.456317 & 0.035188 \\
PURA & 1.299578 & 1.016925 & 1.660796 & 0.036252 \\
FGF13 & 1.436342 & 1.019623 & 2.023374 & 0.038348 \\
TCF21 & 1.217575 & 1.009436 & 1.468631 & 0.039576 \\
RARRES1 & 1.129291 & 1.002043 & 1.272699 & 0.046215 \\
\hline & & & &
\end{tabular}


Supplementary Table 3. Characteristics of the 5 genes in the signature.

\begin{tabular}{llc}
\hline Gene symbol & Gene title & Coefficient \\
\hline LYPD1 & LY6/PLAUR domain containing 1 & -0.02463 \\
DCN & decorin & 0.021033 \\
RARRES1 & retinoic acid receptor responder 1 & 0.033396 \\
PEG3 & paternally expressed 3 & 0.047122 \\
IGF2 & insulin like growth factor 2 & 0.105386 \\
\hline
\end{tabular}

